\title{
Administrative Mediation in Environmental Disputes
}

\author{
Xin Xu \\ Oxbridge College, Kunming University of Science and Technology, Kunming, Yunnan, China
}

Keywords: Environmental Administrative Mediation, Environmental Tort Disputes, Definition, Difficulties.

\begin{abstract}
At present, China is in a period of rapid social transformation, and due to the complexity of different kinds of interests, there are different types of social contradictions and disputes. The purpose of the law is to balance the interests of self-interest and altruism, thus establishing a partnership between individuals and individuals and between individuals and society. With the increasing of environmental pollution and ecological damage, the number of environmental disputes has increased dramatically. This paper strives to improve the necessity of the administrative mediation system of environmental disputes in China from the aspects of law, theory and practice.
\end{abstract}

\section{The introduction of the problem}

Modern civilization breeds harmony, but the process of modernization is the breeding of turbulence. The number of environmental disputes is increasing, and it is also characterized by diversification and complexity. The contradiction between the maximization of personal interests and the scarcity of environmental resources is exacerbating this trend. With the strengthening of citizens' awareness of environmental rights, the situation of infringement caused by environmental hazards continues to stay in the public view. One side is the profound reform of China's economic system, the profound changes in social structure, the profound adjustment of the interests of the pattern and the profound changes in ideas, the other side of the existing dispute resolution mechanism showed a reduced credibility, the effect is not satisfactory, Coping with the dilemma of failure. Society and the public are calling for a diversified new environment dispute resolution mechanism to ease the pressure of the judicial mediation system and the people's mediation system "powerless" weakness.

\section{Definition and update of the concept of administrative mediation in environmental disputes}

Think to the traditional administrative law, administrative mediation refers to, hosted by state administrative organs to based on state law and policy, to the principle of voluntary by persuading methods of education, make both parties equal consultation, compromise and outside, to reach an agreement, eliminate disputes litigation activities. As an important work of the administrative organ, administrative mediation has an important subsidiary role to realize the goal of administrative management. From the point of view of positive law, the way of this definition is basically consistent with relevant laws and regulations. From the characteristics of administrative mediation, the definition reveals the basic characteristics of administrative mediation, such as the voluntary basis; It is a system of mediation. According to the meaning of administrative mediation, administrative mediation in environmental disputes, is due to the request of the environmental civil disputes if one party or both parties, in a real, on the basis of voluntary, the competent administrative department for environmental protection in accordance with the procedures prescribed by the relevant laws and jurisdiction, as the third person in the middle and on the environment civil dispute mediation. In fact, the latter is included in the former, which is a general and special relationship, which is also a response to objective reality, and an update to the concept and mode of government governance. 


\section{On the basis of administrative mediation of environmental disputes}

Theoretical basis. Environmental public welfare. Environmental system is an interrelated and interacting whole. It is a dynamic system, which is interdependent and interactive through continuous material circulation and energy flow. Environmental systems conserve water resources, regulate the nature of the climate, so that people enjoy all kinds of benefits. This function reflects the nature of the public goods of the environment - this property is exclusive, anyone can enjoy, and the enjoyment of any person is not exclusive, can not exclude the enjoyment of other people.

The basis of legal norms. Article 26 of the Constitution of the People's Republic of China clearly stipulates that the state protects and improves the living environment and ecological environment, and controls pollution and other pollution. It can be seen that this is the constitutional basis for all the legal normative documents on the protection of environmental resources by the Government. In October 2010, the State Council promulgated the Opinions on Strengthening the Construction of the Government under the Rule of Law, and clarified the need to resolve social contradictions according to law and improve the social dispute settlement mechanism. In addition, in the Beijing University of law information network, type "mediation" word for full-text search and found that the administrative mediation involving a total of 27 , administrative regulations 31 . These legal normative documents provide a rich legal basis for administrative mediation in environmental disputes.

\section{Endogenous dilemma: the objective impossibility of environmental administrative mediation system in environmental tort disputes"}

Legislative carding of environmental administrative mediation in China. Type "mediation" in university legal information network, and no special "administrative mediation" laws and administrative regulations named text, legal normative documents on other administrative mediation scattered in different departments of law. Among them, the provisions of administrative mediation by special chapters, only sporadic provisions to describe. In terms of the content of the law, the provisions of the law on administrative mediation are mostly more principled and vague. From the main body, scope, procedures and effectiveness of the four dimensions, there are no specific and explicit provisions. The concept of administrative mediation is not coordinated and unified in legislation, some are called administrative treatment, some are called administrative mediation, and the other is called administrative mediation. Therefore, the concept of administrative mediation is not clear and too rough in legislation. Secondly, the laws and regulations on environmental dispute mediation are too simple and principles. The proper settlement of environmental disputes requires perfect executive legislation, that is, legislative activities carried out by laws, regulations or normative documents issued by higher authorities. The executive legislation does not require the creation of new legal norms, but only the standardization of laws and regulations and the standardization documents of higher authorities, so as to implement and implement them. Executive legislation generally adopts the implementation rules, implementation measures, legal interpretation and other forms of expression. Therefore, the normative document of environmental protection law can not be too simplistic and principled, otherwise it is not consistent with its own characteristics of executive legislation. At the same time, in the mediation of environmental civil disputes, the authorization of the administrative organs by our law is not clear and specific, and the functions of different environmental protection administrative organs overlap and overlap. Finally, the lack of corresponding supporting system.

With the rapid development of China's economy, environmental disputes are increasing, the scope of environmental damage continues to expand, the consequences continue to increase, the causes of more and more complex. Because there is no specific support system support, leading to a series of problems. The complexity of environmental infringement disputes leads to the difficulty of obtaining evidence on the one hand and the loss of evidence on the other hand. In the case of environmental infringement, one is due to the lack of evidence of the citizens of the means of evidence, the quality of water, air pollution and the degree of nothing at all, no professional testing equipment and technology, 
can not get first-hand evidence; Of the material, often dangerous chemicals, professional evidence still need to "fully armed", be careful, not to mention the ordinary victims of citizens, the potential risk of evidence can be seen; three evidence often violent obstruction, personal safety Not to protect; Fourth, assessment, identification of high costs, the general victims of the people can not afford.

The Practical Dilemma of China 's Current Environmental Administrative Mediation System. Any kind of legal system should solve the problem in the real world, except the system itself should have the scientific and rational logic system, must undergo the test of the practice, and has the operability. The existing problems of environmental administrative mediation include the following aspects: first, the establishment of unreasonable institutions and lack of professional personnel allocation. The administrative mediation organization of environmental disputes in China sets unreasonable and unscientific and lacks the consideration of professionalism, independence and neutrality. The mediation of environmental disputes is only part of the work of the environmental protection department, and many environmental protection departments are reluctant to deal with these "little things". Second, the environmental disputes in our country, the administrative mediation personnel professional knowledge is not enough, did not receive professional training, professional quality is not high, the lack of professional skills, solve the environmental dispute is difficult to guarantee the quality and efficiency of mediation, and easy to cause the business capability and impartiality of the administrative organs deal with disputes by the consequences of the doubts of the parties. Second, the conciliation procedure is not specific and operable. Administrative mediation lacks specific procedures. The scope and extent of the investigation, the period of conciliation, the final effect of conciliation, etc. are not legally prescribed. Due to the lack of relatively complete procedural law, the environmental administrative organs are likely to lead to the pursuit of efficiency regardless of the fairness phenomenon. Third, there is a poor connection with justice. Recognition of the importance of environment department cohesive mechanism of mediation is not enough in place, and the unbalanced development between regions, there is the economic developed areas, the economy of underdeveloped regions in doing relatively lags behind reality. Though many places has been already established pluralistic mediation mechanism, but in their own way of mediation mechanism, three big mediation system is a lack of effective cohesion, difficult to form effective resources integration. In addition, because the administrative mediation behavior is a typical administrative fact behavior, it does not have the coercive force and execution force, which causes us to solve the environmental dispute satisfactorily. In the process of administrative mediation, if one side, back or refuse to honor the agreement will make the other party filed a civil lawsuit, this waste of both administrative and judicial resources, and reduce the authority of the administrative mediation agreement. At the same time, the people's court lacks proper respect for administrative mediation, and the result of administrative mediation may not be recognized by the society and often overturned by the people's court.

\section{Epilogue: the way out of the dilemma of administrative mediation system in environmental disputes}

Perfect legislation. The above analysis has shown that China's current administrative mediation legislation is still lagging behind, more unable to respond to environmental disputes in the administrative mediation of the real needs. This is very unfavorable to the Chinese society that is in transition. In view of the comparative advantage of administrative mediation in relation to people's mediation and judicial mediation, especially administrative reconsideration, administrative litigation is weak in resolving contradictory ability. In the future, the perfection of administrative mediation system still has a long way to go. First, strengthen the legislative work of administrative mediation and formulate unified legislation. Further clarify and define the concept of administrative mediation, which is the prerequisite and basis for the establishment of administrative mediation of environmental disputes in China. Secondly, under the condition of combining China's national conditions, it is necessary to draw lessons from the advanced legislative experience of Japan and other countries to perfect the administrative mediation laws and regulations of China's environmental disputes. For 
example: Japan as early as 1970, promulgated the "Public Opinion Dispute Resolution Law", the law established the administrative handling mechanism of public security disputes, the purpose is the spirit of private law in the spirit of the premise, through the mediation of the executive authorities, mediation, etc., to promote the parties Between the mutual concessions, in order to seek a prompt and satisfactory settlement of public security disputes. The "pollution" refers to the pollution caused by industrial and human activities, water pollution, soil pollution, noise pollution, ground sinking and odorous smell, so that against human health and living conditions. In my opinion, in the current situation, China should advance the "Environmental Dispute Administrative Mediation Law", clearly defined the administrative agency of the specialized agencies, personnel, procedures and effectiveness. We should also establish a body that specifically manages the identification and assessment of pollution damage, formulate detailed procedures and criteria for accreditation, and determine the calculation method of compensation.

Strengthen the construction of administrative mediation team. We should set up a dispute settlement body that is responsible for the mediation of this industry in the departments of conflict and conflict. It is also possible to establish and improve the grass-roots administrative mediation organization according to the characteristics of the basic level. At present condition has yet to mature, the government should set up specifically responsible for the environment civil dispute administrative mediation agencies, can draw lessons from the United States, Japan, Korea, France and other countries experiences, such as the environmental protection departments at the grassroots government set up a committee of "environmental dispute resolution" and other functions, specifically responsible for the environment civil dispute mediation. The administrative mediation organization shall have the corresponding independence, and the mediation work shall not be interfered by administrative organs, social organizations and individuals; Neutrality, mediation staff should have professional quality, the best made up of men and have professional background, from the civil servants, the legal professionals or experts in employment, can also from the staff of the industry associations or organizations at the grass-roots level in selection, according to the characteristics of the case, get different personnel to participate in mediation, but in each environment disputes, mediation personnel must have a legal professionals, to ensure that the legal effect of mediation from the aspects of law It has certain authority and has the right to investigate and collect evidence externally, and the agreement reached by it has certain enforcement force. At the same time, the environmental dispute mediation committee at all levels shall be responsible for the environmental dispute settlement within the jurisdiction under the principle of territorial jurisdiction, and the environmental disputes of the region shall be handled at the level of level.

Standardize the administrative mediation procedure in environmental disputes, and clarify the legal effect of administrative mediation agreement. Perfect procedures can guarantee the fairness of the results. Combined with the practice of environmental laws and regulations and environmental management in China, the administrative mediation procedures in environmental disputes should generally include six basic steps: "start - receive - mediation - contract - archive feedback". Each step should be specified, for example, the way the program starts, can be divided into the way to start the application and ex officio start, the key is to clear the two start-up methods of their own start. For those difficult to complex cases, in particular, may lead to mass incidents of contradictions and disputes, the executive authorities must take the initiative to mediate. On the issue of convergence with the judiciary, in my opinion, the core lies in the effectiveness of the administrative mediation agreement. Professor Zhang Zhiyuan as the representative of the scholars suggested that you can follow the "People's Mediation Law" Article 33 of the provisions of the provisions of the administrative mediation agreement is legally binding, to give the people's court to confirm the administrative mediation agreement to enforce the force. The opinion of the "draft of the draft" drafted by the Renmin University of China is that the court has confirmed that the effective administrative mediation agreement is the same as the court's formal judgment; the mediation agreement with money, securities or other payment content, the parties The right to apply for court enforcement under a mediation agreement. There are also some experts agree that it is recommended that after the occurrence of environmental disputes, the parties have the right to choose the remedies, 
but should follow the principle of choice but the final. The parties either choose administrative mediation or choose a court action. After the choice of administrative mediation, no further prosecution of the court, the court for environmental administrative organs have been mediation of environmental disputes may not be accepted.

\section{References}

[1] Cai Shouqiu, "On the Government's environmental responsibility of the defects and sound" Hebei law, 2008 No. 3

[2] Xue Gangling, "on administrative behavior and de facto behavior", Politics and Law Forum, 1993 fourth issue

[3] Pan dry, "on the improvement of China's administrative mediation system," Administration and Law, 2008 No. 3

[4] Liu Chao, "omissions and make up: environmental infringement solution in the advance and retreat of the environmental administrative mediation system", Henan Province, the Institute of Political Science and Law, No. 3, 2011

[5] Zhang Zhiyuan, Gu Qinfang, "Chinese legal text in the" administrative mediation "research", JAC Forum, No. 5, 2011

[6] Feng Zhidong, "Dispute Settlement Mechanism External System Environment Optimization", Journal of Gansu Institute of Administration, No. 1, 2012

[7] Liu Peng, "' big mediation "vision to improve China's administrative mediation system thinking", socialism research, the fifth issue of 2012

[8] Beijing University Legal Information network:

Http://www.pkulaw.cn/? Range=0\&menu_item=law\&key_word=\%B5\%F7\%BD\%E2

[9] Zhang Zhengzhao, Hu Jinguang, editor in chief "administrative law and administrative procedure law" (Fourth Edition), Renmin University of China press, published in 2009

[10] Xu Xiangming, editor in chief "ecological civilization construction and environmental public interest litigation", intellectual property rights publishing house, published in 2011

[11] Wang Kejin, editor in chief "administrative public interest litigation system research", Shandong University press, published in 2009

[12] Li Changqi, editor in chief "economic law concept research", Law Publishing House, published in 2009

[13] Xu Xin, "on the government of citizen's environmental rights protection", Heihe journal, 2012 second

[14] Chen Kuo-Fu, editor in chief of "law and economics", Economic Science Press, published in 2006 